\title{
Comparative Study of the Biochemical Response Behavior of Some Highly Toxic Minerals on Selenosis in Rats
}

\author{
LOAI ALJERF ${ }^{1 *}$, MIKE WILLIAMS ${ }^{2}$, ATEM BETHEL AJONG ${ }^{3}$, \\ UKAOGO PRINCE ONYDINMA ${ }^{4}$, FAROUK DEHMCHI ${ }^{5}$, VIET TY PHAM ${ }^{6}$, \\ SUHASINI BHATNAGAR ${ }^{7}$, NASSER BELBOUKHARI ${ }^{8}$
}

${ }^{1}$ Key Laboratory of Organic Industries, Department of Chemistry, Faculty of Sciences, Damascus University, Damascus, Syria

27101M, USEPA, William Jefferson Clinton Building North (WJC North) 1200 Pennsylvania Avenue N.W. Washington, DC 20004, USA

${ }^{3}$ Kekem District Hospital, Kekem, West Region, Cameroon; Department of Biochemistry, University of Dschang, Dschang, West Region, Cameroon

${ }^{4}$ Analytical/Environmental Unit, Department of Pure and Industrial Chemistry, Abia State University, Uturu, Nigeria

${ }^{5}$ Chemistry Department, Badji Mokhtar University, Annaba, Algeria

${ }^{6}$ Faculty of Chemistry, Hue University of Education, 34 Le Loi Str., Hue city, Vietnam

${ }^{7}$ Swaroop Enterprises and Biotech Pvt. Ltd., Noida UP, India

${ }^{8}$ Bioactive Molecules \& Chiral Separation Laboratory, University of TM Bechar, Bechar 08000, Algeria

\begin{abstract}
Many researchers have studied the metabolism of toxics including selenium (Se) in biological medium in rats and defined some correlations between selenium and other minerals as arsenic (As), cadmium (Cd), mercury $(\mathrm{Hg})$, and thallium ( $\mathrm{Tl})$. An investigation of the potential influences of As, $\mathrm{Hg}$, $\mathrm{Tl}$ and $\mathrm{Pb}$ on Se metabolism, which can suggest new drugs to cope the poisonousness of Se. The current study also has looked into the potential use of $A s(I I I) / A s(V)$ toxic in the treatment of essential mineral Se in the animals (as rats) based on sequestration of these toxic elements into biologically inert complexes, reflecting the enormous interest in this subject. The acute studies have been initially achieved by shaping the pulmonary and biliary excretions of the volatile Se in neonatal masculine Holtzman rats which were injected with selenite subcutaneously in the hind flank, then the volatile Se was trapped in $8 \mathrm{~N} \mathrm{HNO}_{3}$ and the radioselenate detected in a scintillation counter. The chronic cases were carried out with the nursing of rats with a purified diet of water-soluble vitamin mix, fat-soluble vitamin mix, saccharides, oil, and salts. One week after the basic diet, the rats taken Se have received diets containing $10 \mathrm{ppm}$ of the element as sodium selenite $\left(\mathrm{Na}_{2} \mathrm{SeO} \mathrm{O}_{3}\right)$ or selenate $\left(\mathrm{Na}_{2} \mathrm{SeO}_{4}\right)$ added in the salts. The calorimeter was used to analyze Se in the frozen tissue specimens. As, $\mathrm{Hg}$, and $\mathrm{Tl}$ were repressed the volatized Se excreted from the lungs. As has assisted the biliary excretion of Se and inhibited the chronic selenosis. Tl has increased the retention of Se in the liver and kidney, but, had no chronic effect on the amount of Se deposited in all the studied tissues. Similarly, $\mathrm{Hg}$ has increased the retention of Se but in the spleen and carcass of rats indicating to the high Se concentration in blood. Hg and Tl have inhibited the Se in urine. No effects of the doses rich in As, $\mathrm{Hg}$, and $\mathrm{Tl}$ on the Se excretion in fecal. Even though, we suggest As as a possible medication to chronic selenosis.
\end{abstract}

Keywords: Biological medium, New drug, Poisonousness of Se, Biliary excretion, Tissue, Carcass, Cancer cell

\section{Introduction}

Recently, many countries have posed several legislations [1] and slated very specific strategies [2] in pharmaceutical industry that serve health challenge [3]. However, these created new modifying rules and regulations should control the added ingredients to the drugs including minerals and radioactive materials but in innocuous quantities [1,2]. These supplemented constituents to the pharmaceutical products should be analyzed in reliable analytical procedures [4] which must satisfy the international pharmacological standards [2]. But the problem is that these principles of the aforementioned

\footnotetext{
*email: loai789.aljerf@damascusuniversity.edu.sy
} 
legislations are sometimes affected by the uncertainties of the toxicology of some metals and metalloids. For instance, a high concentration of organic arsenic (As) compounds is found in many kinds of seafood. These are nontoxic arsenobetaine (finfish and shellfish) and potentially toxic arsenosugars (seaweed) and arsenolipids (fish oils) [5]. As a consequence, we believe that, the health risk posed by seafoodderived As still needs evaluation due to the lack of data on its toxicity and chronic exposure in humans and other mammals. Although, four organoarsenic drugs, namely roxarsone, carbasone, arsanilic acid, and nitarsone, were used for many years as veterinary feed additives to prevent certain diseases in poultry, in 2014 and 2015, the U.S. Food and Drug Administration formally withdrew the approval for the use of these animal drug products.

What is more, As and selenium (Se) are unusual metalloids as they both induce and cure cancer. They both cause carcinogenesis, pathology, cytotoxicity, and genotoxicity in humans, with reactive oxygen species playing an important role [6]. The fulfillment of Se functions in animals mainly depends on the expression of selenoproteins. This small (25 selenoproteins in humans) but pivotal group of proteins includes among others glutathione peroxidases (GPxs) and thioredoxin reductase (TrxR) participating in redox state regulation and antioxidant defense, idothyronine deiodinases (DIOs) required for thyroid hormone synthesis and metabolism, GPx4 playing specific roles in spermatogenesis, and selenoprotein $S$ involved in immune responses. While As induces adverse effects by decreasing DNA methylation and affecting protein 53 expression, Se induces adverse effects by modifying thioredoxin reductase [7]. They can react with glutathione and S-adenosylmethionine by forming an As-Se complex, which can be secreted extracellularly. Since then, Se deficiency has been linked directly or indirectly with a large variety of animal and human disorders. Dietary Se prevents liver necrosis in vitamin Edeficient. Nevertheless, there still exist contradictory reports as both synergistic and antagonistic toxicity between As and Se. Consequently, the relation between As and Se has attracted increasing attention.

Among such trials, Hamid et al. [8] has stimulated much research concerning the metabolism of toxic elements as selenium. This element is mostly existed in biological medium as selenite $\left(\mathrm{SeO}_{3}{ }^{-2}\right)$ and selenate $\left(\mathrm{SeO}_{4}{ }^{-2}\right)$. Selenite is called as gypsum flower, desert rose, satin spar, and satin spar are four assortments of mineral crystals of gypsum. Those four kinds of gypsum can be assembled together and termed selenite [9]. The selenite anion is a Se oxoanion of a formula $\mathrm{SeO}_{3}{ }^{-2}$. A selenite is a compound of this ion. Under weak acidic conditions, hydrogenselenite ion, $\mathrm{HSeO}_{3}{ }^{-}$, is formed; however, in higher acid cases, selenous acid $\mathrm{H}_{2} \mathrm{SeO}_{3}$, occurs. It is more required in minute quantities for the proper growth, development, and physiology of an organism [10] $\mathrm{SeO}_{3}{ }^{-2}$ exacerbates hepatic insulin resistance in mouse model of type II diabetes through oxidative stress-mediated JNK pathway [11]. In A549 cancer cells, the discerning increment of SOD1 content is accompanied with $\mathrm{SeO}_{3}{ }^{-2}$ generation of superoxide radical anions and this boosts apoptosis and $\mathrm{Se}-\mathrm{Cu}$ linkage [10]. On the other hand, selenate is a sturdy dibasic acid with molecular formula $\left(\mathrm{H}_{2} \mathrm{SeO}_{4}\right)$, so it is an acid form of inorganic salts of dihydrogen selenium tetraoxide. It is toxic by dust ingestion, inhalation or skin contact. Selenate is naturally occurring or synthetic substances that inhibit or retard oxidation reactions. They counteract the damaging effects of oxidation in animal tissues [9].

By hand, several metabolic interrelationships among minerals and Se are instituted [12,13]. As represses Se toxicity [14,15] and diminishes Se retention in mice' livers [16]. This advantageous trait of As is owing to the augmented clearance of Se from liver into bile [17].

$\mathrm{Cd}$ inhibits Se detoxification and forms volatile methylated Se compounds, so results in increasing Se retained in liver [18-20]. Nonetheless, $\mathrm{Cd}$ in rats which causes testis injury can be protected by Se [20-22].

Endemic human selenosis was described very thoroughly by studies of Se-excessive regions of China located in Western Hubei Province and Southern Shaanxi Province, where high Se content in soils, water, and corn was identified [23]. The dietary intake of Se in the regions affected by selenosis estimated in the 1970s was 3.2-6.8 mg/day [23]. Due to the lower dependence on locally grown food, no human cases of selenosis have been reported in those areas since 1987 [23]. During the last years, cases of selenosis in humans induced by environmental exposure to Se were reported in the state of 
Punjab, India, where the disease was caused by excessive Se content in locally grown grains [24]. Acute Se poisoning resulting in a massive alopecia was also described in a 55-year-old woman who ingested paradise nuts (Lecythis ollaria) [25]. Moreover, as reported by some epidemiologic studies, even lowlevel but chronic overexposure to Se, for example from drinking water, may be associated with adverse health effects in humans such as an increased risk of amyotrophic lateral sclerosis and cancer [26].

Novel studies show that $\mathrm{Se}$ can protect against $\mathrm{Hg}$ and $\mathrm{Tl}$ toxification [27-30]. The aim of the current study was to compare the influences of $\mathrm{As}, \mathrm{Hg}, \mathrm{Tl}$, and $\mathrm{Pb}$ on Se metabolism. It was concluded that As, $\mathrm{Hg}$, and $\mathrm{Tl}$ all repressed the pulmonary excreted amount of Se volatilized compounds, but that As alone was capable to improve the excretion of Se in bile. As was also the only cooperating tested element that reduced the chronic Se poisoning effects.

\section{Materials and methods}

Acute studies. Nursling male of Holtzman rats (in small bowels, one contained significantly lower concentrations of adenosine - $3^{\prime}, 5^{\prime}$ - cyclic monophosphate than all the others) (Photo 1) was nourished a stock diet [30] for 2-3 weeks and their pulmonary excretions of exhausted Se compounds were assessed.

The animals were shot subcutaneously in one hind flank with the appropriate test element in physiological saline and then 10 min later in the opposite hind flank with $2 \mathrm{mg}$ Se per $\mathrm{kg}$ as sodium selenite $\left(\mathrm{Na}_{2} \mathrm{SeO}_{3}\right)$ containing approximately 1 microcurie $(\mu \mathrm{Ci})$ of $\mathrm{H}_{2}{ }^{75} \mathrm{SeO}_{3}$ (Preliminary observation: a formation of dimethylselenide $\left(\mathrm{CH}_{3}\right)_{2} \mathrm{Se}$ and dimethyldiselenide $\left(\mathrm{CH}_{3}\right)_{2} \mathrm{Se}_{2}$ in the breath of the rats). For capturing the exhausted Se, the animals were left $12 \mathrm{~h}$ in all-glass metabolism cages furnished with sintered-glass scrubbers containing $8 \mathrm{~N} \mathrm{HNO}_{3}$. The rats were sacrificed, and the tissues were isolated for direct measurement of radioactivity in a well-type scintillation counter (Perkin Elmer Tri-Carb). Data are expressed as percentage of the dose of labeled selenium injected.

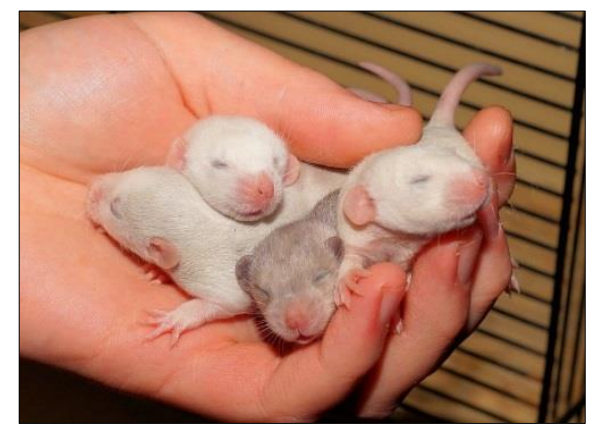

Photo 1. Newborn

Holtzman rat males

In newborn Holtzman male rats nursed a routine diet, Se excretion from the bile has been investigated. The bile ducts have been cannulated as described in many works [31-33]. In one flank, about $0.5 \mu \mathrm{Ci}$ of radioactive Se in physiological saline was subcutaneously injected, and the participating element was given in the opposite flank.

Dose and timing schedules are registered in Tables 1-3. Where required, radioselenate was made by a repetitive digestion of radioselenite with conc. $\mathrm{HNO}_{3}[34,35]$. Bile was collected for $1 \mathrm{~h}$ and the radioactivity was detected in a well-type scintillation counter. Data are expressed as percentage of the dose of labeled selenium injected.

\section{Chronic studies}

Neonatal masculine Holtzman rats were nourished a purified diet which included the following components in $\mathrm{g} / \mathrm{kg}$ : sucrose $\left(\mathrm{C}_{12} \mathrm{H}_{22} \mathrm{O}_{11}\right)$, 710; casein $\left(\mathrm{C}_{38} \mathrm{H}_{57} \mathrm{~N}_{9} \mathrm{O}_{9}\right)$, 200; corn oil (calories and total fat were 122 and $21 \%$, respectively) 50; salts [36], 35; water-soluble vitamin mix, 2; fat-soluble vitamin mix, 2; and choline chloride $\left.\left(\mathrm{CH}_{3}\right)_{3} \mathrm{NCH}_{2} \mathrm{CH}_{2} \mathrm{OH}\right] \mathrm{Cl}, 1$. The water-soluble vitamin mix contained, in mg/g: myo-inositol $\left(\mathrm{C}_{6} \mathrm{H}_{12} \mathrm{O}_{6}\right), 100$; nicotinic acid (vitamin $\mathrm{B} 3$ (VB3), $\mathrm{C}_{6} \mathrm{H}_{5} \mathrm{NO}_{2}$ ), 11; calcium pantothenate (Ca salt of water-soluble VB5, $\mathrm{C}_{18} \mathrm{H}_{32} \mathrm{CaN}_{2} \mathrm{O}_{10}$ ), 6; riboflavin (VB2, $\mathrm{C}_{17} \mathrm{H}_{20} \mathrm{~N}_{4} \mathrm{O}_{6}$ ), 2; 
pyridoxine. $\mathrm{HCl}$ (4-methanol form of $\mathrm{VB} 6, \mathrm{C}_{8} \mathrm{H}_{12} \mathrm{ClNO}_{3}$ ), 1; thiamine. $\mathrm{HCl}\left(\mathrm{VB} 1, \mathrm{C}_{12} \mathrm{H}_{18} \mathrm{Cl}_{2} \mathrm{~N} 4 \mathrm{OS}\right.$ ), 1 ; folic acid (VB9, $\mathrm{C}_{19} \mathrm{H}_{19} \mathrm{~N}_{7} \mathrm{O}_{6}$ ), 0.1; $d$-biotin (VB7, $\mathrm{C}_{19} \mathrm{H}_{19} \mathrm{~N}_{7} \mathrm{O}_{6}$ ), 0.1; VB12, 0.005; sucrose $\left(\mathrm{C}_{12} \mathrm{H}_{22} \mathrm{O}_{11}\right.$ ), 878.8. The fat-soluble vitamin mixture supplied, per $\mathrm{kg}$ of diet, $3000 \mathrm{IU}$ of crystalline VA, $2000 \mathrm{IU}$ of VD3, $90 \mathrm{mg}$ of dl- $\alpha$-tocopherol $\left(\mathrm{C}_{31} \mathrm{H}_{52} \mathrm{O}_{3}\right)$, and $150 \mu \mathrm{g}$ of menadione $\left(\mathrm{C}_{6} \mathrm{H}_{4}(\mathrm{CO})_{2} \mathrm{C}_{2} \mathrm{H}\left(\mathrm{CH}_{3}\right)\right)$. The rats were distributed into sets of analogous mean weights and launched their investigational diets after one week on basal food regime.

The rats fed selenium received diets containing 10 ppm of the element as $\mathrm{Na}_{2} \mathrm{SeO}_{3}$ or $\mathrm{Na}_{2} \mathrm{SeO}_{4}$ added in the salts. So that, the tested elements were participated by means of their soluble salts at a level of 10 ppm in the potable water to examine their impacts on Se metabolism and toxification. The weights were logged twice each 7-days. The living rats were sacrificed and checked for gross pathological lesions. Samples of tissues were frozen and saved for selenium analysis by calorimetry [37-40].

\section{Results and discussions}

\subsection{Acute studies}

$30 \%$ of the dosage was exhaled as Se volatilized shape in $12 \mathrm{~h}$ of injecting the control animals with $2 \mathrm{mg} \mathrm{Se} / \mathrm{kg}$ as $\mathrm{SeO}_{3}{ }^{-2}$ and saline (Table 1). The quantity of the volatilized Se was diminished to 5.4\% of dosage when the rats were administered $4 \mathrm{mg} \mathrm{As} / \mathrm{kg}$ as arsenite $\left(\mathrm{AsO}_{2}^{-}\right)$. Even the animals needed higher dosages, but we registered a pulmonary Se excretion inhibition when $\mathrm{Hg}$ or $\mathrm{Tl}$ was administered. High dosages of $\mathrm{Pb}(48 \mathrm{mg} / \mathrm{kg})$ did not show any effect on the Se circulation or volatilization. However, the noticeable reduction of the Se volatilized shape during As and $\mathrm{Hg}$ treatment was followed with high levels of Se in the kidney and carcass. Treatment with $\mathrm{Tl}$ had retained higher amounts of Se in the kidney and liver. Possibly due to the Se increasing concentrations in the gastrointestinal innards, high quantities of Se in the carcass were enrolled when As has been taken [41]. In addition, probably due to the extremely high concentration of Se in blood, the retention of this element in carcass has been noticed during $\mathrm{Hg}$ intake. This is not just the interesting notice with $\mathrm{Hg}$ administration in rats, nevertheless, we also observed a large amount of Se retained in spleen.

Table 1. Effect of $\mathrm{AsO}_{2}{ }^{-}$and the collaborated chemical elements on $\mathrm{SeO}_{3}{ }^{-2}$ metabolism by rats

\begin{tabular}{|c|c|c|c|c|c|c|c|c|}
\hline \multirow{2}{*}{$\begin{array}{c}\text { Chemical } \\
\text { form and } \\
\text { dosage of test } \\
\text { elements } \\
(\mathrm{mg} / \mathrm{kg})\end{array}$} & \multicolumn{8}{|c|}{ Proportion of the dose of selenium $(\%)^{a}$} \\
\hline & $\begin{array}{c}\text { Volatile } \\
\text { compounds }\end{array}$ & Liver & Kidney & Carcass $^{\mathrm{c}}$ & Spleen & $\begin{array}{c}\text { Blood, } \\
\text { mL }\end{array}$ & Feces & Urine \\
\hline None & $30.6 \pm 3.72$ & $11.3 \pm 0.02$ & $1.90 \pm 0.11$ & $20.2 \pm 1.07$ & $0.20 \pm 0.05$ & $0.80 \pm 0.16$ & $1.10 \pm 0.54$ & $14.7 \pm 2.38$ \\
\hline $\mathrm{NaAsO}_{2}-4$ & $5.40 \pm 0.74$ & $8.65 \pm 0.01$ & $5.02 \pm 0.29$ & $42.8 \pm 1.70$ & $0.10 \pm 0.05$ & $0.40 \pm 0.02$ & $0.40 \pm 0.32$ & $16.0 \pm 0.97$ \\
\hline $\mathrm{HgCl}_{2-12}$ & $8.70 \pm 2.11$ & $15.8 \pm 0.84$ & $4.23 \pm 0.27$ & $37.4 \pm 0.60$ & $1.80 \pm 0.11$ & $1.70 \pm 0.20$ & $0.50 \pm 0.20$ & $7.80 \pm 1.60$ \\
\hline TlAc-12 & $5.90 \pm 1.27$ & $37.5 \pm 6.20$ & $9.83 \pm 0.52$ & $17.9 \pm 1.20$ & $0.30 \pm 0.00$ & $0.42 \pm 0.00$ & $0.90 \pm 0.21$ & $6.33 \pm 0.50$ \\
\hline $\mathrm{Pb}(\mathrm{Ac})_{2}-48$ & $32.6 \pm 2.40$ & $13.7 \pm 2.65$ & $2.17 \pm 0.36$ & $21.3 \pm 1.40$ & $0.34 \pm 0.10$ & $1.15 \pm 0.40$ & $0.92 \pm 0.50$ & $13.9 \pm 0.60$ \\
\hline \multicolumn{9}{|c|}{$\begin{array}{l}\text { Distribution of radioactivity } 12 \text { hours after subcutaneous injection of } 2 \mathrm{mg} \text { of Se per kilogram body weight containing } \\
\text { approximately } 1 \mu \mathrm{Ci}^{75} \mathrm{Se} \text { as } \mathrm{H}_{2}{ }^{75} \mathrm{SeO}_{3} \text {; mean of four animals } \pm \text { standard error; weight range of animals } 119-189 \mathrm{~g} \text {. } \\
\text { b Before injecting with Se by } 10 \mathrm{~min} \text {., the rat has been injected with saline solution or the test element subcutaneously. } \\
{ }^{\mathrm{c}} \text { Includes gastrointestinal contents. }\end{array}$} \\
\hline
\end{tabular}

No treatment of the groups in any of these short-interim testing was affected Se fecal excretion, but the depressing properties of $\mathrm{Tl}$ and $\mathrm{Hg}$ on $\mathrm{Se}$ in urine were recorded. Similar to the Experiment $\mathrm{A}$ presented in Table 2, in another study [31], As has promoted Se bile excretion. Animals receiving only selenium excreted about $1 \%$ of the dose in the bile in $1 \mathrm{~h}$ whereas animals receiving both arsenic and selenium excreted over $20 \%$ of the dose of selenium in the same time interval. Under similar tentative conditions, trials of using $\mathrm{Hg}, \mathrm{Tl}$, or $\mathrm{Pb}$ were failed to initiate $\mathrm{Se}$ excretion from the bile. 
Table 2. Effect of $\mathrm{AsO}_{2}{ }^{-}$and heavy metals (i.e. $\mathrm{Hg}, \mathrm{Tl}, \mathrm{Pb}$ ) on $\mathrm{Se}$ excretion in bile

\begin{tabular}{|c|c|c|c|}
\hline \multicolumn{2}{|c|}{ Chemical form and dosage (mg element/kg) } & \multicolumn{2}{|c|}{ Proportion of the dose of selenium $(\%)^{d}$} \\
\hline Selenium & Test element & Bile & Liver \\
\hline \multicolumn{4}{|c|}{ Experiment $\mathrm{A}^{\mathrm{e}}$} \\
\hline $\mathrm{Na}_{2} \mathrm{SeO}_{3}-0.5$ & None & $1.18 \pm 0.20$ & $28.6 \pm 1.01$ \\
\hline $\mathrm{Na}_{2} \mathrm{SeO}_{3}-0.5$ & $\mathrm{NaAsO}_{2}-1$ & $21.2 \pm 4.47$ & $10.6 \pm 1.73$ \\
\hline $\mathrm{Na}_{2} \mathrm{SeO}_{3}-0.5$ & $\mathrm{HgCl}_{2}-1$ & $1.50 \pm 0.32$ & $28.8 \pm 1.51$ \\
\hline $\mathrm{Na}_{2} \mathrm{SeO}_{3}-0.5$ & TlAc-1 & $0.90 \pm 0.25$ & $29.3 \pm 2.96$ \\
\hline $\mathrm{Na}_{2} \mathrm{SeO}_{3}-0.5$ & $\mathrm{~Pb}(\mathrm{Ac})_{2-1}$ & $1.08 \pm 0.11$ & $28.9 \pm 0.74$ \\
\hline $\mathrm{Na}_{2} \mathrm{SeO}_{4}-0.5$ & None & $0.90 \pm 0.13$ & $22.0 \pm 2.57$ \\
\hline $\mathrm{Na}_{2} \mathrm{SeO}_{4}-0.5$ & $\mathrm{NaAsO}_{2}-1$ & $3.90 \pm 3.69$ & $8.10 \pm 1.32$ \\
\hline $\mathrm{Na}_{2} \mathrm{SeO}_{4}-0.5$ & TlAc-1 & $0.90 \pm 0.21$ & $19.7 \pm 2.08$ \\
\hline \multicolumn{4}{|c|}{ Experiment $\mathrm{B}^{\mathrm{f}}$} \\
\hline $\mathrm{Na}_{2} \mathrm{SeO}_{3}-2.4$ & None & $0.34 \pm 0.00$ & $15.0 \pm 0.50$ \\
\hline $\mathrm{Na}_{2} \mathrm{SeO}_{3}-2.4$ & $\mathrm{HgCl}_{2}-4$ & $0.35 \pm 0.00$ & $15.6 \pm 0.80$ \\
\hline \multicolumn{4}{|c|}{ Experiment $\mathrm{C}^{\mathrm{g}}$} \\
\hline $\mathrm{Na}_{2} \mathrm{SeO}_{3}-4.2$ & None & $0.17 \pm 0.00$ & $10.2 \pm 0.60$ \\
\hline $\mathrm{Na}_{2} \mathrm{SeO}_{3}-4.2$ & TlAc-30 & $0.19 \pm 0.01$ & $27.4 \pm 0.70$ \\
\hline $\mathrm{Na}_{2} \mathrm{SeO}_{4}-4.2$ & None & $0.33 \pm 0.00$ & $10.3 \pm 0.30$ \\
\hline $\mathrm{Na}_{2} \mathrm{SeO}_{4}-4.2$ & TlAc-30 & $0.23 \pm 0.50$ & $16.5 \pm 1.80$ \\
\hline \multicolumn{4}{|c|}{$\begin{array}{l}\text { d Distribution of radioactivity } 1 \text { hour after subcutaneous injection of stated dose of selenium containing approximately } 0.5 \\
\mu \mathrm{Ci}^{75} \mathrm{Se} \text { as } \mathrm{H}_{2}{ }^{75} \mathrm{SeO}_{3} \text { or } \mathrm{H}_{2}{ }^{75} \mathrm{SeO}_{4} \text {; weight range of animals } 344-403 \mathrm{~g} \text {; mean of three or four animals } \pm \text { standard error. } \\
{ }^{\mathrm{e}} \mathrm{Se} \text { injection followed by } 10 \text { min. the saline or the specified test element injection subcutaneously. } \\
{ }^{\mathrm{f}} \mathrm{Se} \text { injection after } 1 \text { hour of injection subcutaneously with the saline or the specified dose of } \mathrm{Hg} \text {. } \\
{ }_{\mathrm{g}} \mathrm{Se} \text { injection after } 2 \text { hrs. of injection subcutaneously with the saline or the specified dose of Tl. }\end{array}$} \\
\hline
\end{tabular}

Yet, As may possess diverse impacts on Se metabolism depending on the time interval between injections, valance state, and dose of the elements [42,43]. Similar reports to the current experiments had demonstrated an antagonism effect of Se against $\mathrm{Tl}$ and $\mathrm{Hg}$ [42-45]. Even though, according to the Experiments B \& C in Table 2 and under the prespecified conditions, $\mathrm{Tl}$ and $\mathrm{Hg}$ have not exhibited any effect on Se excretion from the bile. Likewise, that was also right once $\mathrm{Tl}$ was experienced along with $\mathrm{Se}$ introduction as selenate $\left(\mathrm{SeO}_{4}{ }^{-2}\right)$ in lieu of $\mathrm{SeO}_{3}{ }^{-2}$.

\subsection{Chronic studies}

Conferring to Experiment $\mathrm{A}$ in Table 3, As was the one tested element that shielded rats against chronic selenosis [46] as ruled by 3-unlike measures: reduced liver damage, reduced Se retention in diverse tissues, and high mass gains. Under parallel conditions, compared to the rats which did not fed $\mathrm{Se}$, these animals that received $\mathrm{Se}+$ As have exercised no substantial growth-promoting effect even they showed growing mass gain (the mass gain of control and As treated animals was $235 \pm 9.80$ and $249 \pm 15.5$ $\mathrm{g}$, respectively, $\mathrm{P}>0.3$ ). This cluster of rats which supplemented $\mathrm{Se}+\mathrm{As}$ exhibited quite pretty normal on gross checkup, even just a few showed a little grainy appearance. However, an extreme plain form of liver injury was observed uniform with seleniferous control. $\mathrm{Hg}$ administration to the animals has associated with mass gain in analogy to the As set, however, they conveyed ascites fluid. Besides, the survival was lowermost archived in this set and the liver damage has been largely dominant in the control set who acknowledged Se alone. Thallium did not improve weight gains although in this group there was a slightly favorable effect against liver damage due to selenium. Giving the results of Experiment $\mathrm{B}$ that presented in Table 3 and in equivalent to the previous tests, $\mathrm{Tl}$ and Se provided as $\mathrm{SeO}_{4}{ }^{-2}$ in lieu of $\mathrm{SeO}_{3}{ }^{-2}$, has shaped parallel outcomes. As component critically depressed the quantity of Se reserved in the tissues of animal nourished enduring contents of Se, despite the rats possibly assimilated extra meal comprising this element, as evinced by their larger mass gains. Hg was virtually not active as As, in spite of, the first element leaned to decline to a certain degree the Se retained in liver and kidney. Tl did not demonstrate any effect on the precipitated Se content in the tissues of the animal administered $\mathrm{Se}$ as $\mathrm{SeO}_{3}{ }^{-2}$. Moreover, the latter testing element (Tl) was fairly diminished the quantity of the $\mathrm{Se}$ 
compounds retained in livers of $\mathrm{SeO}_{4}{ }^{-2}$-fed rats. However, more notably, Tl resulted an increase in the content of Se observed in kidney.

Table 3. Effect of $\mathrm{AsO}_{2}{ }^{-}$and heavy metals in chronic selenosis

\begin{tabular}{|c|c|c|c|c|c|}
\hline \multirow{2}{*}{$\begin{array}{l}\text { Salt in drinking } \\
\text { water }^{\mathrm{h}}\end{array}$} & \multirow{2}{*}{$\begin{array}{l}\text { Weight gain } \\
\text { (g) }\end{array}$} & \multirow[t]{2}{*}{ Survival } & \multirow{2}{*}{$\begin{array}{c}\text { Gross liver } \\
\text { damage }\end{array}$} & \multicolumn{2}{|c|}{ Se content $(\mu \mathrm{g} / \mathrm{g}$ wet weight $)$} \\
\hline & & & & Liver & Kidney \\
\hline \multicolumn{6}{|c|}{ Experiment $A^{i}$} \\
\hline None & $68.9 \pm 8.91$ & $9 / 10$ & Severe & $7.64 \pm 2.10$ & $36.8 \pm 2.76$ \\
\hline $\mathrm{NaAsO}_{2}$ & $116 \pm 16.3$ & $8 / 10$ & Mild & $2.72 \pm 0.20$ & $11.5 \pm 2.30$ \\
\hline $\mathrm{HgCl}_{2}$ & $105 \pm 34.3$ & $4 / 7$ & Severe & $6.60 \pm 0.90$ & $24.3 \pm 4.82$ \\
\hline TIAc & $70.0 \pm 8.25$ & $6 / 7$ & $\begin{array}{c}\text { Moderately } \\
\text { severe }\end{array}$ & $7.48 \pm 0.60$ & $33.3 \pm 6.50$ \\
\hline \multicolumn{6}{|c|}{ Experiment $B^{j}$} \\
\hline None & $75.0 \pm 8.50$ & $6 / 7$ & Severe & $22.1 \pm 5.80$ & $42.5 \pm 6.61$ \\
\hline TlAc & $72.0 \pm 11.9$ & $6 / 7$ & $\begin{array}{l}\text { Moderately } \\
\text { severe }\end{array}$ & $14.3 \pm 1.70$ & $104.4 \pm 5.30$ \\
\hline \multicolumn{6}{|c|}{$\begin{array}{l}{ }^{\mathrm{h}} \text { Add at level of } 10 \mathrm{ppm} \text { of the test element. } \\
{ }^{\mathrm{i}} \text { After } 7 \text { weeks on a diet containing } 10 \mathrm{ppm} \mathrm{Se} \mathrm{as} \mathrm{SeO}_{3}{ }^{-2} \text {; mean } \pm \text { standard error. } \\
\text { j After } 7 \text { weeks on a diet containing } 10 \mathrm{ppm} \mathrm{Se} \text { as } \mathrm{SeO}_{4}{ }^{-2} \text {. }\end{array}$} \\
\hline
\end{tabular}

\subsection{Metabolic detoxification activity}

The studied metals as Arsenic are taken up by plants as they grow - this means they make their way into our food, even that it does not build up in the body [6]. Both inorganic and organic forms of Arsenic leave human body in urine. Most of the inorganic arsenic will be gone within several days, although some will remain in body for several months or even longer. If exposed to organic arsenic, most of it will leave the body within several days. Methyl groups bind to arsenic and help remove it from the body. Arsenic appears to have toxic effects on neurotransmitters involved in cell-to-cell signaling within the brain. We expect from our experience, that in humans, arsenic-induced regional increases in levels of dopamine, serotonin, and their metabolites and also induced a decrease in norepinephrine levels in discrete brain regions, the event which needs more investigations by next researchers.

Due to the complexity of human internal environment, the process of how As interferes with Se metabolism is susceptible to multi-factors (nutritional status, health status and dietary habits), which may result in different effect [6]. This makes the synergistic effects between As and Se toxicity in humans under question. We hypothesize that there are two types of interactions between As and Se. At low concentration, Se can decrease As toxicity via excretion of As-Se compound $\left[(\mathrm{GS} 3)_{2} \mathrm{AsSe}\right]^{-}$, but at high concentration, excessive Se can enhance As toxicity by reacting with $\mathrm{S}$-adenosylmethionine and glutathione, and modifying the structure and activity of arsenite methyltransferase.

The current findings establish an exceptional aptitude of As to develop the excretion of Se bile and lessen Se toxification. The chronically selenized animals taken As showed a reduction in the Se retained in livers, makes it look as if appear that the valuable factor of As in chronic selenium poisoning is probably related to the increased Se excretion into the bile of As-handled rats. The later action of As performance on biliary $\mathrm{Se}$ is left over for further deep investigations to explain this important mechanism.

Ostensibly, Se pulmonary excretive reduction per se did not entail adequate conditions for enhancing Se excretion in bile, probably for a reason that $\mathrm{As}$, $\mathrm{Tl}$, and $\mathrm{Hg}$ can impede the biosynthesis of Se volatile compounds. However, As is the sole among the other tested elements that has enthused the excretion of Se in bile. Likewise, the augmented quantity of Se in the bile of As-handled animals has not seemed to be associated to a wide-ranging infiltration of As on the active thiol functional groups of structural 
proteins or enzymes [47-50] attributing to the only fact that $\mathrm{Pb}, \mathrm{Tl}$, and $\mathrm{Hg}$ all attack and strongly react with thiol groups (sulfhydryl, $-\mathrm{SH}$ ) as well [51] and might be expected to mimic the effect of arsenic where this the lone factor involved.

The probability of constructing specific selenoarsenic conjugates as purifying agents excreted into the bile is being deliberated beforehand [14]. Nevertheless, the present biochemical fractionation investigations that propose an incidence of numerous diverse forms of biliary Se, lean towards rejecting this supposition.

Here, we think, the arsenic activity have interfered in the adjustment of the expression of oxidative stress-related genes, which controlled the extent of Se that improved the activities of antioxidant enzymes, and in turn protected liver cells from As-induced oxidative damage. Besides, the balance between As and Se concentrations have maintained the body's capability of As methylation which involves the reductive thioredoxin (Trx) system. In fact, the As-Se conjugate, namely a seleno-bis(Sglutathionyl) arsinium ion [(GS) $\left.{ }_{2} \mathrm{AsSe}\right]^{-}$is nontoxic which has been identified in the bile of experimental rabbits and rats $[52,53]$ and the precise mechanism of $[(\mathrm{GS}) 2 \mathrm{AsSe}]^{-}$generation has been thoroughly described in review articles by Gailer [54] and Sun et al. [55]. Accordingly, hydrogen selenide (HSeproduced from selenite in the presence of GSH) reacts inside erythrocytes and probably hepatocytes with $(\mathrm{GS})_{2} \mathrm{As}-\mathrm{OH}$ (produced in the reaction of arsenite and GSH), forming a nontoxic complex selenobis(Sglutathionyl) arsinium ion $\left[(\mathrm{GS})_{2} \mathrm{AsSe}\right]^{-}$. Once formed, the $\left[(\mathrm{GS})_{2} \mathrm{AsSe}\right]^{-}$species are removed out of the cells followed by rapid excretion via the liver and bile into the intestinal tract [56]. The complex $\left[(\mathrm{GS})_{2} \mathrm{AsSe}\right]^{-}$is proposed to play a role of a detoxification product which protects the mammalian organism from arsenite toxicity.

\section{Conclusions}

The metabolism of Se is reliant on the valency state and the dose amount of the elements, in addition to the interval period among shoots. From the results of this research, we refer clearly to the antagonism property including biliary excretion of Se against $\mathrm{Hg}$ and $\mathrm{Tl}$. As compounds have successfully proved themselves as a medication of liver damage, which can be suggested as supplemented ingredients in releasing Se from various tissues. Not even that, Se, regardless of its form (as selenite, selenomethionine, nanoSe, or Se from lentils), can reduce As toxicity in the liver, kidney, spleen, brain, or heart in animal models. Se antagonizes the toxicity of As mainly through sequestration of this element into biologically inert complexes and/or through the action of Se-dependent antioxidant enzymes. An increase in the As methylation efficiency is proposed as a possible mechanism by which Se can reduce As toxicity. It is expected that Se may diminish As toxicity by activation of the nuclear factor erythroid 2-related factor (Nrf2) pathway. The well-known antioxidant selenoenzymes such as GPx and TrxR also mediate Sedependent detoxification of $\mathrm{As}$ and $\mathrm{Cd}$, but they probably play a secondary role. Therefore, the interactive benefits of taking arsenic in selenosis are more profitable than its endemic risks.

More studies are needed to investigate the mechanism of the valuable arsenic performance in treating biliary selenium. Further, this paper suggests studying possible signs of As toxic effects, which may be a challenge for its future use in the therapy of Se poisoning in humans and provide future directions to address this issue.

\section{References}

1.ALJERF, L., Syrian medical legislation impacts stories on pharmacy in the millennium. Chronicles of Pharmaceutical Science., 1(5), 2017, 307-311.

2.ALJERF, L., ALMASRI, N., An assessment of the US and UN safety precautions for pesticides in milk by labeling medicine alarm strategy for all dairy animal products. International Journal of Drug Safety and Discovery., 2(1), 2018, 009.

3.ALJERF, L., ALHAMWI, B., Carbon nanotubes - synthesis developmental engineering demands will overcome the health challenge of nanotoxicity and its acute mortality for humans. Madridge Journal of Nanotechnology \& Nanoscience., 3(2), 2018, 118-121. 
4.ALJERF, L., BEASLEY, K., SMITH, B., GANESHAN, N., Glass chromatography application: TLC separation of benzoic esters in pharmaceutical products. International Journal of Biochemistry Advances., 1(1), 2017, 1-8.

5.TAYLOR, V., GOODALE, B., RAAB, A., SCHWERDTlE, T., REIMER, K., CONKLIN, S., KARAGAS, M.R., FRANCESCONI, K.A., Human exposure to organic arsenic species from seafood. Sci. Total Environ., 580, (2017), 266-282.

6.ALJERF, L., ALJURF, M., Improvements in the Ecological and Nutritional Aspects of Downs Syndrome. Preprints., 2020, 2020050512. https://doi.org/10.21203/rs.3.rs-30313/v1

7.ROMAN, M., JITARU, P., BARBANTE, C., Selenium biochemistry and its role for human health. Metallomics., 6(1), 2014, 25-54.

8.HAMID, M., ABDULRAHIM, Y., LIU, D., QIAN, G., KHAN, A., HUANG, K., The hepatoprotective effect of selenium-enriched yeast and gum Arabic combination on carbon tetrachloride-induced chronic liver injury in rats. J. Food Sci., 83(2), 2018, 525-534.

9.MOLNAR, Á, FEIGL, G., TRIFAN, V., ÖRDOG, A., SZOLLOSI, R., ERDEI, L., KOLBERT, Z., The intensity of tyrosine nitration is associated with selenite and selenate toxicity in Brassica juncea $\mathrm{L}$. Ecotoxicol. Environ. Saf., 147, 2018, 93-101.

10.NAKAZAWA, Y., PAUZE, M., FUKUYAMA, K., NAGAI, N., FUNAKOSHI-TAGO, M., SUGAI, T., TAMURA, H., Effect of hesperetin derivatives on the development of selenite-induced cataracts in rats. Mol. Med. Rep., 18(1), 2018, 1043-1050.

11.ZHOU, J., XU, G., BAI, Z., LI, K., YAN, J., LI, F., MA, S., XU, H., HUANG, K., Selenite exacerbates hepatic insulin resistance in mouse model of type 2 diabetes through oxidative stress-

mediated JNK pathway. Toxicol. Appl. Pharmacol., 289(3), 2015, 409-418.

12.ALJERF, L., ALMASRI, N., A gateway to metal resistance: bacterial response to heavy metal toxicity in the biological environment. Annals of Advances in Chemistry., 2(1), 2018, 32-44.

13.ALJERF, L., ALMASRI, N., Mercury toxicity: ecological features of organic phase of mercury in biota- Part I. Archives of Organic and Inorganic Chemical Sciences., 3(3), 2018, 1-8.

14.CSANAKY, I., GREGUS, Z., Effect of selenite on the disposition of arsenate and arsenite in rats. Toxicol., 186(1-2), 2003, 33-50.

15.ISSAM, S., NAWEL, N., YASSINE, C., Selenium alleviates the arsenic toxicity in sunflower seedling. J. Adv. Biol. Biotechnol., 3(3), 2015, 101-109.

16.SUZUKI, Y., HASHIURA, Y., MATSUMURA, K., MATSUKAWA, T., SHINOHARA, A., FURUTA, N., Dynamic pathways of selenium metabolism and excretion in mice under different different selenium nutritional statuses. Metallomics., 2(2), 2010, 126-132.

17.COLOMBO, C., SETCHELL, K.D.R., PODDA, M., Liver dysfunction in cystic fibrosisbeneficial effect of bile acid treatment. Gastroenterol., 100(5), 1991, 1476-1477.

18.JAMALL, I.S., SMITH, J.C., Effects of cadmium treatment on selenium-dependent and selenium independent glutathione peroxidase activities and lipid peroxidation in the kidney and liver of rats maintained on various levels of dietary selenium. Arch. Toxicol., 58(2), 1985, 102-105.

19.SZAKOVA, J., ZIDEK, V., MIHOLOVA, D., Influence of elevated content of cadmium and arsenic in diet containing feeding yeast on organisms of rats. Czech J. Anim. Sci., 54(1), 2009, 1-9.

20.RANA, S.V.S., BOORA, P.R., Antiperoxidative mechanisms offered by selenium against liver injury caused by cadmium and mercury in rat. Bull. Environ. Contam. Toxicol., 48(1), 1992.

21.SHIRAISHI, K., NAITO, K., YOSHIDA, K.I., Inhibition of calpain but not caspase protects the Testis against injury after experimental testicular torsion of rat. Biol. Reprod., 63(5), 2000, 1538-1548. 22.ŞLENCU, B.G., Protective effects of selenium of hepatotoxicity caused by subacute experimental combined exposure to cadmium and lead in rats. Farmacia., 66(5), 2018, 866-876.

23.LI, S., XIAO, T., ZHENG, B., Medical geology of arsenic, selenium and thallium in China. Sci. Total Environ., 421-422, 2012, 31-40.

24.RAZMI, T.M., ATTRI, S.V., HANDA, S., Haemorrhagic onychomadesis: a cutaneous clue to chronic selenosis-case series. J. Eur. Acad. Dermatol. Venereol., 31(9), 2017, e425-e427. 
25.SENTHILKUMARAN, S., BALAMURUGAN, N., VOHRA, R., THIRUMALAIKOLUNDUSUBRAMANIAN, P., Paradise nut paradox: alopecia due to selenosis from a nutritional therapy. Int. J. Trichol., 4(4), 2012, 283-284.

26.VINCETI, M., CRESPI, M.C., BONVICINI, F., MALAGOLI, C., FERRANTE, M., MARMIROLI, S., STRANGES, S., The need for a reassessment of the safe upper limit of selenium in drinking water. Sci. Total Environ., 443, 2013, 633-642.

27.KRAMAR, R., ULRICH, W., HOHENEGGER, M., Severe sublimate intoxication in the rat. Exp. Pathol., 36(2), 1989, 97-103.

28.BAIZ, N, CHASTANG, J., IBANEZ, G., ANNESI-MAESANO, I., Prenatal exposure to selenium may protect against wheezing in children by the age of 3. Immunity, Inflammation and Disease., 5(1), 2016, 37-44.

29.TUDOR, M., Potential protective role of selenium in experimental subacute intoxication with ethephon in rats. Farmacia., 66(3), 2018, 463-467.

30.FINLEY, J.W., The absorption and tissue distribution of selenium from high-selenium Broccoli are different from selenium from sodium selenite, sodium selenate, and selenomethionine as determined in selenium-deficient rats. J. Agri. Food Chem., 46(9), 1998, 3702-3707.

31.GREGUS, Z., GYURASICS, Á., KOSZORUS, L., Interactions between selenium and group Vametalloids (arsenic, antimony and bismuth) in the biliary excretion. Environ. Toxicol. Pharmacol., 5(2), 1998, 89-99.

32.LARSEN, G.L., Intermediary metabolism of pentachloronitrobenzene in the control and germfree rat and rat with cannulated bile ducts. Xenobiotica., 28(10), 1998, 973-984.

33.MORISAWA, Y., TAKIKAWA, H., Effect of bile acids on the biliary excretion of pravastatin in rats. Hepatol. Res., 39(6), 2009, 595-600.

34.AWWAD, H.K., EL SHERAKI, A.S., EL SHETAIWI, S., HELMI, S., Production of radiosulphate and radioselenate, and their reutilisation following injection of 35S-cystine and 75Selenocystine. Int. J. Appl. Radiat. Isot. 24(2), 1973, 91-97.

35.FEIST, L.J., PARKER, D.R., Ecotypic variation in selenium accumulation among populations of Stanleya pinnata. New Phytol., 149(1), 2001, 61-69.

36.ANI, I., Biochemical effects of some traditional Nigerian diets in experimental diabetic rat models. Int. J. Biochem. Res. Rev., 2(2), 2012, 70-77.

37.STONE, W.L., DRATZ, E.A., Selenium and non-selenium glutathione peroxidase activities in selected ocular and non-ocular rat tissues. Exp. Eye Res., 35(5), 1982, 405-412.

38.DOKOUPILOVA, A., MAROUNEK, M., SKRIVANOVA, V., BREZINA, P., Selenium content in tissues and meat quality in rabbits fed selenium yeast. Czech J. Anim. Sci., 52(6), 2008, 165-169. 39.ZOIDIS, E., DEMIRIS, N., KOMINAKIS, A., PAPPAS, A.C., Metaanalysis of selenium accumulation and expression of antioxidant enzymes in chicken tissues. Animal., 8(4), 2014, 542-554.

40.PAVLOVIC, Z., MILETIC, I., ZEKOVIC, M., NIKOLIC, M., GLIBETIC, M., Impact of selenium addition to animal feeds on human selenium status in Serbia. Nutrients., 10(2), 2018, 225.

41.KIRCHGESSNER, M., GABLER, S., WINDISCH, W., Homeostatic adjustments of selenium metabolism and tissue selenium to widely varying selenium supply in 75Se labeled rats. J. Anim. Physiol. Anim. Nutr., 78(1-5), 1997, 20-30.

42.ISHIZAKI, M., UENO, S., OKAZAKI, T., SUZUKI, T., OYAMADA, N., Interaction of arsenic and selenium on the metabolism of these elements in hamsters. Appl. Organomet. Chem., 2(4), 1988, 323331.

43.JANASIK, B., ZAWISZA, A., MALACHOWSKA, B., FENDLER, W., STANISLAWSKA, M., KURAS, R., WASOWICS, W., Relationship between arsenic and selenium in workers occupationally exposed to inorganic arsenic. J. Trace Elem. Med. Biol., 42, 2017, 76-80.

44.STANEVICIENE, I., BERNOTIENE, R., SADAUSKIENE, I., The comparison of the protective effect of zinc and selenite ions against cadmium induced changes of protein synthesis in mice organs. Trace Elem. Electroly., 31, 2014, 116-123. 
45.TURGUT, B., ERGEN, I., ILHAN, N., The protective effect of sesamol in the selenite-induced experimental cataract model. Turk. J. Ophthalmol., 47, 2017, 309-314.

46.KEZHOU, W., STOWE, H.D., HOUSE, A.M., CHOU, K., THIEL, T., Comparison of cupric and sulfate ion effects on chronic selenosis in rats. J. Anim. Sci., 64(5), 1987, 1467-1475.

47.GREGUS, Z., Effects of arsenic-, platinum-, and gold-containing drugs on the disposition of exogenous selenium in rats. Toxicol. Sci., 57(1), 2000, 22-31.

48.TANGUY, S., BESSE, S., DUCROS, V., DE LEIRIS, J., BOUCHER, F., Effect of increased dietary selenium intake on blood and cardiac selenium status during aging in rats. Nutr. Res., 23(2), 2003, 239243.

49.GAILER, J., Arsenic-selenium and mercury-selenium bonds in biology. Coordin. Chem. Rev., 251(1-2), 2007, 234-254.

50.SRIVASTAVA, D., SUBRAMANIAN, R., MADAMWAR, D., FLORA, S., Protective effects of selenium, calcium, and magnesium against arsenic-induced oxidative stress in male rats. Arh. Hig. Rada. Toksikol., 61(2), 2010, 153-159.

51.YANG, S., LIU, Y., Nuclear volume effects in equilibrium stable isotope fractionations of mercury, thallium and lead. Sci. Rep., 5(1), 2015, 12626.

52.GAILER, J., GEORGE, G.N., PICKERING, I.J., PRINCE, R.C., YOUNIS, H.S., WINZERLING, J.J., Biliary excretion of $[(\mathrm{GS})(2)$ AsSe $](-)$ after intravenous injection of rabbits with arsenite and selenate. Chem. Res. Toxicol., 15(11), 2002, 1466-1471.

53.GEORGE, G.N., GAILER, J., PONOMARENKO, O., LA PORTE, P.F., STRAIT, K., ALAUDDIN, M., AHSAN, H., AHMED, S., SPALLHOLZ, J., PICKERING, I.J., Observation of the seleno bis-(Sglutathionyl) arsinium anion in rat bile. J. Inorg. Biochem., 158, 2016, 24-29.

54.GAILER, J., Probing the bioinorganic chemistry of toxic metals in the mammalian bloodstream to advance human health. J. Inorg. Biochem., 108, 2012, 128-132.

55.SUN, H.J., RATHINASABAPATHI, B., WU, B., LUO, J., PU, L.P., MA, L.Q., Arsenic and selenium toxicity and their interactive effects in humans. Environ. Int., 69, 2014, 148-158.

56.PONOMARENKO, O., LA PORTE, P.F., SINGH, S.P., LANGAN, G., FLEMING, D.E.B., SPALlHOLZ, J.E., ALAUDDIN, M., AHSAN, H., AHMED, S., GAILER, J., GEORGE, G.N., PICKERING, I.J., Selenium-mediated arsenic excretion in mammals: a synchrotron-based study of whole-body distribution and tissue-specific chemistry. Metallomics., 9(11), 2017, 1585-1595

$\overline{\text { Manuscript received: } 27.09 .2020}$ 